УДК 615.074:543.422.3

DOI https://doi.org/10.11603/2312-0967.2021.1.11982

\title{
ВАЛІДАЦІЯ МЕТОДИКИ КІЛЬКІСНОГО ВИЗНАЧЕННЯ АЛКІЛБЕНЗИЛДИМЕТИЛАМОНІЙ ХЛОРИДУ МЕТОДОМ ПРЯМОЇ АБСОРБЦІЙНОЇ СПЕКТРОФОТОМЕТРІЇ В ЗАСОБІ ДЕЗІНФЕКЦІЙНОМУ «ВІРОСАН Ф»
}

\author{
М. Я. Смолінська, Г. Ю. Тесляр, І. Я. Коцюмбас, М. В. Юркевич, Л. І. Котяш \\ Державний науково-дослідний контрольний інститут \\ ветеринарних препаратів та кормових добавок \\ boiko_maria@ukr.net
}

\section{ІНФОРМАЦІЯ}

Надійшла до редакції / Received: 12.01.2021

Після доопрацювання / Revised: 29.01.2021

Прийнято до друку / Accepted: 03.02.2021

\section{Ключові слова:}

алкілбензилдиметиламоній хлорид;

активний фрармацевтичний інгредієнт;

четвертинні амонійні сполуки; засоби дезінфекційні; спектрофотометрія; валідація.

\section{АНОТАЦІЯ}

Мета роботи. Розробка та валідація методики кількісного визначення алкілбензилдиметиламоній хлориду із задовільними метрологічними характеристиками у комбінованому деззасобі «Віросан Ф» методом прямої УФ-спектрофротометрії.

Матеріали і методи. Засіб дезінфекційний «Віросан Ф» (ТзОВ «БіоТестЛабораторія» м. Київ), що містить у своєму складі алкілбензилдиметиламоній хлорид (50 мг·мл $\left.{ }^{-1}\right)$, глутаровий діальдегід та формальдегід як діючі речовини, а також допоміжні речовини - синтанол та воду очищену. У роботі використовували вторинний фармакопейний стандартний зразок алкілбензилдиметиламоній хлориду, фрармацевтичні субстанції алкілбензилдиметиламоній хлориду, глутарового діальдегіду, фрормальдегіду та допоміжні речовини фрармакопейної чистоти (SigmaAldrich). Для спектрофротометричного вимірювання використовували скануючий спектрофротометр Cary 50 Scan WinUV-Visible Spectrophotometer (Varian) та кварцові кювети 3 товщиною поглинаючого шару I = 1 см.

Результати й обговорення. Розроблено та проведено валідацію методики прямого спектрофротометричного визначення алкілбензилдиметиламоній хлориду в комбінації з двома альдегідами (глутаровим діальдегідом та формальдегідом) у водних розчинах одного з доволі поширених дезінфекційних засобів «Віросан Ф». Обчислені значення повної прогнозованої непевності не перевищують максимально допустимої систематичної похибки результатів аналізу деззасобу «Віросан Ф». На спектрі розчину плацебо повністю відсутні усі максимуми світлопоглинання, характерні для алкілбензилдиметиламоній хлориду. Відношенняабсорбції розчинуплацебодо абсорбції компенсаційного розчину незначуще порівняно $з$ максимально допустимою систематичною похибкою результатів аналізу. Залежність зміни значень абсорбції модельних та випробовуваних розчинів деззасобу «Віросан Ф» від часу зберігання $\epsilon$ незначущою порівняно 3 максимально допустимою систематичною похибкою результатів аналізу. Визначені параметри лінійної залежності аналітичного сигналу від концентрації алкілбензилдиметиламоній хлориду у модельних розведених розчинах деззасобу «Віросан Ф» відповідають критеріям лінійності, прецизійності і правильності. Величина $\Delta_{\text {intra }}$, обчислена при перевірці внутрішньолабораторної прецизійності, не перевищує максимально допустиму непевність результатів аналізу. Відповідність

ISSN 2312-0967. Pharmaceutical review. 2021. № 1 
усіх валідаційних показників фрармакопейним критеріям $є$ підставою стверджувати, що розроблена методика $є$ придатною для встановлення вмісту алкілбензилдиметиламоній хлориду у досліджуваному деззасобі.

Висновки. Запропоновано нову аналітичну методику кількісного визначення алкілбензилдиметиламоній хлориду в комбінованому дезінфекційному засобі «Віросан Ф» методом прямої абсорбційної спектрофотометрії в ультрасріолетовій області, яка полягає у вимірюванні абсорбції водних розчинів алкілбензилдиметиламоній хлорид за довжини хвилі 268 нм. Розрахунок вмісту запропоновано здійснювати методом стандарту. Результати проведених валідаційних досліджень 3 використанням критеріїв прийнятності для допусків відхилення вмісту від номінального значення $\mathrm{B}= \pm 10 \%$ підтверджують специфрічність, робасність, лінійність, правильність, прецизійність та внутрішньолабораторну прецизійність запропонованої методики у діапазоні їі застосування від $4 \cdot 10^{-4} г \cdot$ мл $^{-1}$ до $6 \cdot 10^{-4} г \cdot$ мл $^{-1}$.

Вступ. Алкілбензилдиметиламоній хлорид (БАХ, бензалконій хлорид, бензил-С 8 -алкілдиметил-амоній хлорид; CAS RN 63449-41-2 та 61789-71-7) - катіоногенна поверхнево-активна речовина, що належить до класу четвертинних амонійних сполук (ЧАС), є сумішшю БАХ, що мають фрормулу [ $\left.\mathrm{C}_{6} \mathrm{H}_{5} \mathrm{CH}_{2} \mathrm{~N}\left(\mathrm{CH}_{3}\right)_{2}-\mathrm{R}\right] \mathrm{Cl}$ (рис. 1), де - $\mathrm{R}$ символізує лінійні алкільні гомологи з парним числом атомів вуглецю від $\mathrm{H}-\mathrm{C}_{8} \mathrm{H}_{17}$ до $\mathrm{H}-\mathrm{C}_{18} \mathrm{H}_{37}$ (найчастіше, саме $\mathrm{H}-\mathrm{C}_{12} \mathrm{H}_{25}$, H- $\mathrm{C}_{14} \mathrm{H}_{29}$ та $\mathrm{H}-\mathrm{C}_{16} \mathrm{H}_{33}$ ), серед яких ланцюг $-\mathrm{C}_{14} \mathrm{H}_{29}$ надає молекулі найбільш виражені бактерицидні властивості.

БАХ був уперше синтезований Г. Домагком у 1935 році [1].

Середня молярна маса БАХ, здебільшого, становить близько 360 г/моль. pH 5 \% (м/м) водного розчину знаходиться у межах 5,0-8,0.

Електронний спектр водних розчинів БАХ в ульт расріолетовій області має інтенсивну смугу поглинання при $\lambda_{\max }=(208 \pm 1)$ нм, а у діапазоні довжин хвиль від 240 нм до 275 нм має три максимуми абсорбції, а саме: $\quad \lambda_{1 \max }=(256 \pm 1) \mathrm{HM}, \quad \lambda_{2 \max }=(262 \pm 1) \mathrm{HM}, \quad$ і $\lambda_{3 \max }=(268 \pm 1)$ нм (рис. 2) [2-4].

За звичайних умов БАХ - білий з ледь жовтуватим відтінком аморфний порошок, легко розчинний у воді, низь-

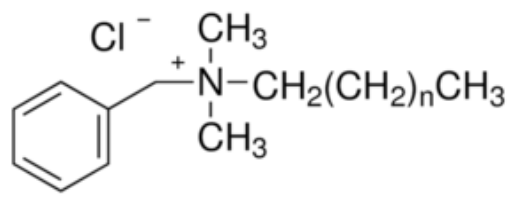

Рис. 1. Структурна фрормула БАХ, де, n = 8, 10, 12, 14, $16,18$.

комолекулярних спиртах та ацетоні, практично нерозчинний у діетиловому етері. Водні розчини є безбарвними, стійкими до змін рН і температури. Несумісні з неіонними та аніоногенними ПАР, протеїнами, перманганатом калію, пероксидами, нітратами, саліцилатами, тартратами, цитратами, алюмінієм і сполуками цинку [5].

БАХ належить до фрармакотерапевтичної групи D08AJ01 - антисептичні препарати.

Розчини БАХ мають біоцидну активність щодо широкого спектра грамнегативних і грампозитивних бактерій, інактивують деякі віруси, включно HIV, мінімально активні проти бактеріальних ендоспор та кислотоутворюючих бактерій, активні проти міцеліальних і дріжджових грибів, одноклітинних водоростей та протозойних, неактивні проти грибних спор.

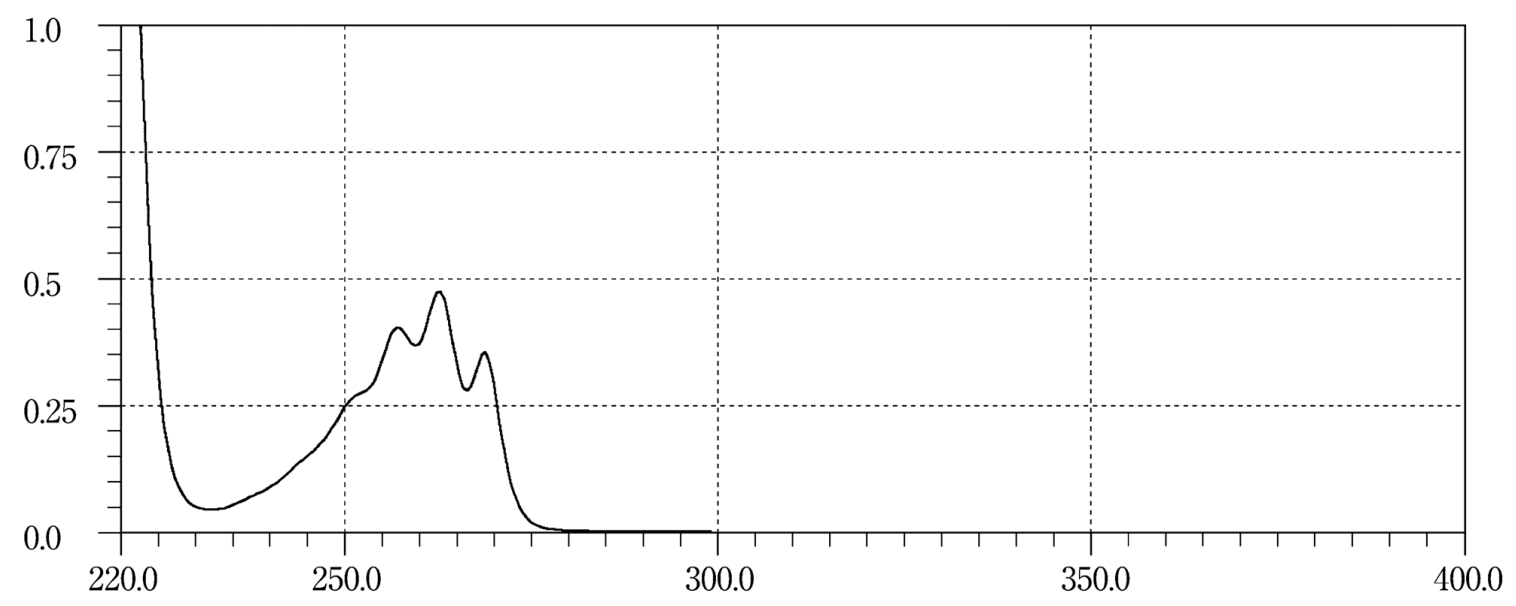

Рис. 2. Еталонний УФ-спектр абсорбції водного розчину алкілбензилдиметиламоній хлориду [4].

ISSN 2312-0967. Фармацевтичний часопис. 2021. № 1 
БАХ як активний фрармацевтичний інгредієнт (АФІ) використовується у фрармацевтичних препаратах як антимікробний чинник. Найбільше використовують в офртальмологічних лікарських препаратах (очні краплі, мазі), а також у краплях для носа, де необхідна відсутність подразливої дії та швидкий бактерицидний ефект [6]. БАХ виявляє активність щодо штамів бактерій, резистентних до антибіотиків та інших хіміотерапевтичних лікарських засобів, зокрема інгібує в клітинах стафрілококів фрерменти плазмокоагулазу та гіалуронідазу. Має сперміцидну активність, що зумовлена здатністю молекул БАХ пошкоджувати мембрани сперматозоїдів. Запобігає вторинному інфрікуванню ран госпітальними штамами мікроорганізмів. Також широко використовується як компонент багатьох дезінфекційних засобів [7], одним 3 яких $€$ «Віросан Ф», виробництва ТзОВ «БіоТестЛабораторія» м. Київ.

BIPOCAН Ф - комплексний мийно-дезінфекційний засіб, діє бактерицидно щодо Bacillus anthracis, Coxiella burneti, E. coli, Klebsiella pneumoniae, Listeria monocytogenes, Mycobacterium tuberculosis, Mycoplasma spp., Proteus mirabilis, Pseudomonas aeruginosa, Salmonella spp., Staphylococcus aureus, Streptococcus faecalis; фрунгіцидно щодо Aspergillus spp., Candida spp., Fusarium spp., Penicillium spp.; вірулецидно щодо Newcastle disease virus, Reovirus, Birnavirus, Rotavirus, Coronavirus, Papillomavirus, Paramyxovirus, Poxvirus, Orthomyxovirus, Pestivirus; а ще альгіцидно та протистоцидно. Цей ДЗ застосовують для дезіноекції тваринницьких та птахівничих приміщень після їх механічного очищення, інкубаторів, для дезінфрекції яєць і тари, пунктів штучного осіменіння, транспортних засобів після їх механічного очищення, поверхонь, об'єктів і обладнання, що підлягають ветеринарному нагляду, а також для заповнення дезбар'єрів [8].

У періодичній науковій літературі для визначання БАХ пропонують спектросоотометричний метод у різних його варіаціях - пряма [9-11], похідна [12], диференційна $[13,14]$ спектрофоотометрія та метод екстракційноспектрофотометричного визначення $[15,16]$. Також знайшли застосування методики з використанням методів високоефективної рідинної (BEPX) [17-20], тонкошарової (ТШХ) [21] та газової (ГX) [22] хроматограсіії, хромато-мас-спектрометрії [23], капілярного електрофрорезу [24], потенціометричного титрування з використанням іон-селективних електродів [25].

Відповідно до вимог Європейської Фармакопеї (Ph. Eur.) [26] та Британської Фармакопеї (ВР) [27] кількісне визначення основної речовини у субстанції БАХ виконують методом двофразного йодометричного титрування з використанням метиленхлориду (Ph. Eur.) та хлороформу (ВР), а згідно з Фармакопеєю США (USP) - методом BEPX [28].

У Державній Фармакопеї України (ДФУ 2.0) [29] відсутня фрармстаття щодо субстанції БАХ. До того ж, у жодній з доступних нам фрармакопей немає відомостей стосовно визначання БАХ у комбінованих засобах. Тому метою роботи були розробка та валідація методики кількісного визначення БАХ із задовільними метрологічними характеристиками у комбінованому деззасобі «Віросан Ф» методом прямої УФ-спектросротометрії.

Матеріали і методи. Об'єкт дослідження: засіб дезінфекційний «Віросан Ф» виробництва ТзОВ «БіоТестЛабораторія» м. Київ, що містить у своєму складі БАХ (50 мг·мл $\left.{ }^{-1}\right)$, глутаровий альдегід та фрормальдегід як діючі речовини, а також допоміжні речовини синтанол та воду очищену [29]. У роботі використовували 50 \% фрармакопейну субстанцію БАХ та вторинний фармакопейний стандартний зразок, що містить 50 мг·мл ${ }^{-1}$ цієї ЧАС, інші діючі та допоміжні речовини фрармакопейної чистоти (Sigma-Aldrich). Як розчинник використовували воду очищену [29].

Спектрофотометричні вимірювання проводили на скануючому спектрофотометрі Cary 50 Scan WinUVVisible Spectrophotometer (Varian), з діапазоном вимірювання світлопоглинання від 190 нм до 1100 нм, 3 роздільною здатністю 1,5 нм, забезпечений кюветами кварцовими 3 довжиною оптичного шляху 1 см.

У роботі використовували посуд лабораторний мірний клас A («Simax», Чехія), електронну вагу AS 220R (RadWag)).

Методика кількісного визначення БАХ у деззасобі «Віросан Ф»

Для проведення випробувань використовували такі розчини:

Вихідний розчин. Деззасіб «Віросан Ф» (ДЗ).

Випробовуваний розчин ДЗ. Близько 2 г (точна наважка) ДЗ, що містить близько 100 мг БАХ, згідно із заявленим його вмістом у ДЗ, розчиняли в 35 мл води очищеної у мірній колбі місткістю 50 мл, доводять об'єм розчину до мірної риски, перемішували. 5 мл цього розчину доводили до мірної риски тим самим розчинником у мірній колбі місткістю 20 мл та ретельно перемішували. Одержаний випробовуваний розчин ДЗ повинен містити близько 0,5 мг БАХ в 1 мл $(0,05 \%)$ і придатний впродовж тижня при зберіганні у герметично закритому посуді за кімнатної температури у захищеному від прямого світла місці.

Стандартний розчин ФСЗБАХ. 50 \% водний розчин вторинного фрармацевтичного стандарту БАХ.

Розчин порівняння. Близько 200 мг (точна наважка) стандартного розчину ФСЗ БАХ розчиняли у 35 мл води у мірній колбі місткістю 50 мл, ретельно перемішували та доводили об'єм розчину до мірної риски тим самим розчинником, перемішували. 5 мл цього розчину доводили до мірної риски тим самим розчинником у мірній колбі місткістю 20 мл та ретельно перемішували. Одержаний розчин порівняння містить 0,5 мг БАХ в 1 мл (0,05\% розчин) і придатний для використання впродовж 1 тижня, при зберіганні у герметично закритому посуді за кімнатної температури у захищеному від прямого світла місці.

модельний розчин ДЗ готували відповідно до складу деззасобу вказаного у нормативній документа-

ISSN 2312-0967. Pharmaceutical review. 2021. № 1 
Аналіз лікарських засобів

\section{Analysis of drugs}

ції, використовуючи 50 \% розчин фрармакопейної субстанції БАХ, а також субстанції інших АФІ та допоміжних речовин фрармакопейної чистоти (Sigma-Aldrich).

Розведений МР ДЗ. 1 г модельного розчину ДЗ розчиняли у 15 мл води в мірній колбі місткістю 25 мл, доводили об'єм розчину до мірної риски, перемішували. 5 мл цього розчину доводили до мірної риски тим самим розчинником у мірній колбі місткістю 20 мл та ретельно перемішували (розведений МР ДЗ). Одержаний розведений МР ДЗ містить 0,5 мг БАХ в 1 мл (0,05 \% розчин) і придатний для використання впродовж 1 тижня, при зберіганні у герметично закритому лабораторному посуді за кімнатної температури у захищеному від прямого світла місці.

Розчин плацебо. Змішували усі інгредієнти, за винятком БАХ, та розводили водою так само, як у випадку приготування розведеного МР ДЗ. Одержаний компенсаційний розчин придатний для використання до повного використання при зберіганні за звичайних умов у герметично закритому лабораторному посуді.

Результати й обговорення. 3 метою ідентифрікації АФІ деззасобу «Віросан Ф» записували спектри поглинання у кюветі кварцовій з товщиною поглинаючого шару $1 \mathrm{~cm}$, приготованих випробовуваного розчину та розчину порівняння, а також розведеного МР Дз і розчину плацебо в УФ-діапазоні від 200 нм до 300 нм, використовуючи воду як компенсаційний розчин. Оцінювали характер та ступінь збігів спектрів зі спектром розчину порівняння (рис. 1). У результаті порівняння спектрів досліджуваних розчинів було визначено, що $\lambda_{\max 3}=268$ нм найбільше відповідає аналітичній довжині хвилі (АДХ) для кількісного визначення вмісту БАХ у деззасобі «Віросан Ф» через те, що саме за цієї АДХ усі інші інгредієнти ДЗ практично не впливають на величину оптичного поглинання БАХ.

Для кількісного вмісту БАХ у деззасобі «Віросан Ф» аналогічно вимірювали величину оптичного поглинання випробовуваного розчину ДЗ та розчину порівняння проти компенсаційного розчину.
Вміст БАХ $(X)$, в мг/мл, у деззасобі «Віросан Ф» (вихідний розчин) розраховували за фрормулою:

$$
X=\frac{m_{с 3} \cdot P_{c 3} \cdot E_{п р .} \cdot \rho_{п р .}}{m_{п р .} \cdot E_{c 3}}
$$

де $m_{c з}$ - маса (точна наважка) стандартного розчину ФСЗ БАХ, використана для приготування розчину порівняння, мг;

$m_{п р}$ - маса (точна наважка) вихідного розчину, що містить БАХ, і використана для приготування випробовуваного розчину ДЗ, г;

$E_{c з}-$ значення оптичної густини розчину порівняння;

$P_{c з}$ - вміст основної речовини у ФСЗ БАХ згідно 3 сертифрікатом якості фрірми-виробника, \%;

$E_{\text {пр }}$ значення оптичної густини випробовуваного розчину ДЗ:

$\rho_{\text {пр }}$ густина ДЗ, г/мл.

Усі валідаційні випробування та обчислення проводили відповідно до вимог ДФУ 2.0, т. 1, с. 910 [29] та рекомендацій Eurachem-Ukraine [30, 31].

Максимально допустима непевність результату аналізу $\Delta_{A s}$ при допусках вмісту В $=10$ \% становить:

$$
\Delta_{\text {As }} \leq B \cdot 0,32=10 \cdot 0,32=3,2 \%
$$

Максимально допустима систематична похибка становить:

$$
\max \delta \leq \Delta_{A s} \cdot 0,32=3,2 \cdot 0,32=1,02 \%
$$

\section{Розрахунок непевності результату аналізу}

Розрахунок непевності результатів аналізу проводили відповідно до методики пробопідготовки зразків для аналізу. У таблиці 1 наведено окремі складові непевності: непевність зважування, непевність мірного посуду - колб та піпеток класу А, що наведені у ДФУ 2.0.

\begin{tabular}{|c|c|c|}
\hline Операція пробопідготовки & $\begin{array}{c}\text { Параметр } \\
\text { розрахункової фрормули }\end{array}$ & $\begin{array}{c}\text { Значення непевності виконаних } \\
\text { операцій пробопідготовки }\end{array}$ \\
\hline \multicolumn{3}{|c|}{ Розчин порівняння } \\
\hline 1. Відбір наважки ФСЗ БАХ & $\mathrm{m}_{0}$ & $0,1 \%$ \\
\hline 2. Доведення до об’єму в мірній колбі 50 мл & 50 & $0,17 \%$ \\
\hline 3. Відбір аліквоти піпеткою 5 мл & 5 & $0,37 \%$ \\
\hline 4. Доведення до об'єму в мірній колбі 20 мл & 20 & $0,28 \%$ \\
\hline \multicolumn{3}{|c|}{ Випробовуваний розчин ДЗ } \\
\hline 5. Відбір наважки досліджуваного препарату & $\mathrm{m}_{0}$ & $0,02 \%$ \\
\hline 6. Доведення до об’єму в мірній колбі 50 мл & 50 & $0,17 \%$ \\
\hline 7. Відбір аліквоти піпеткою 5мл & 5 & $0,37 \%$ \\
\hline 8. Доведення до об'єму в мірній колбі 20 мл & 20 & $0,28 \%$ \\
\hline
\end{tabular}

\section{Таблиця 1}

Результати обчислення непевності пробопідготовки при визначенні вмісту БАХ

ISSN 2312-0967. Фармацевтичний часопис. 2021. № 1 
Обчислена непевність пробопідготовки становить:

$$
\Delta_{S P}=\sqrt{0,1^{2}+0,02^{2}+2 \cdot 0,17^{2}+2 \cdot 0,37^{2}+2 \cdot 0,28^{2}}=\sqrt{0,4988}=0,71 \% .
$$

Непевність кінцевої аналітичної операції становить:

$$
\Delta_{F A O}=1,65 \cdot \sqrt{\frac{2 \cdot\left(S_{A}^{2}+S_{c e l l}^{2}\right)}{3}}=1,65 \cdot \sqrt{\frac{2 \cdot\left(0,2^{2}+0,1^{2}\right)}{3}}=0,30 \% .
$$

Повна прогнозована непевність результатів аналізу становить:

$$
\Delta_{A S}=\sqrt{\left(\Delta_{S P}\right)^{2}+\left(\Delta_{F A O}\right)^{2}}=\sqrt{0,71^{2}+0,30^{2}}=0,77 \% \leq 1,02 \% .
$$

\section{Специфрічність}

Електронні спектри поглинання випробовуваного розчину Дз, розчину порівняння, розведеного МР ДЗ та розчину плацебо (рис. 3) реєстрували за вказаних у розробленій методиці умов.

Було встановлено, що інші інгредієнти і допоміжні речовини деззасобу «Віросан Ф» не мають значущого пливу на абсорбцію БАХ при обраній АДХ. Цей висновок зроблено, виходячи із розрахунку відношення абсорбції розчинів плацебо і розведеного МР ДЗ, яке $€$ незначущим порівняно з максимально допустимою систематичною похибкою:

$$
\delta=\frac{A_{p l}}{A_{m}} \cdot 100=\frac{0,0006}{0,4189} \cdot 100=0,14 \% \leq 1,02 \%,
$$

де, $A_{p l}$ - оптична густина розчину плацебо; $A_{m}$ - оптична густина розведеного МР ДЗ; 100 - фрактор перерахунку результату у відсотки.

\section{Робасність}

Результати визначення стійкості випробовуваних розчинів у часі показані у таблиці 2. Абсорбцію розчину плацебо та розведеного МР ДЗ вимірювали через 15 хв, 30 хв, 45 хв та 60 хв.

Лінійність, правильність, прецизійність

Лінійність

Лінійність залежності абсорбції від концентрації БАХ досліджували в межах діапазону застосування розробленої аналітичної методики, для чого готували 9 розведених МРДЗ, які одержували розбавленням модельного розчину ДЗ до концентрацій БАХ, що становили від 80 \% до 120 \% відносно вмісту вказаного виробником (рис. 4). Паралельно, за вказаних умов, вимірювали абсорбцію розчину порівняння.

У таблиці 3 наведено первинні дані, отримані при дослідженні лінійності.

Нормалізовані значення концентрацій БАХ у розведених МРДЗ наведені у таблиці 4.

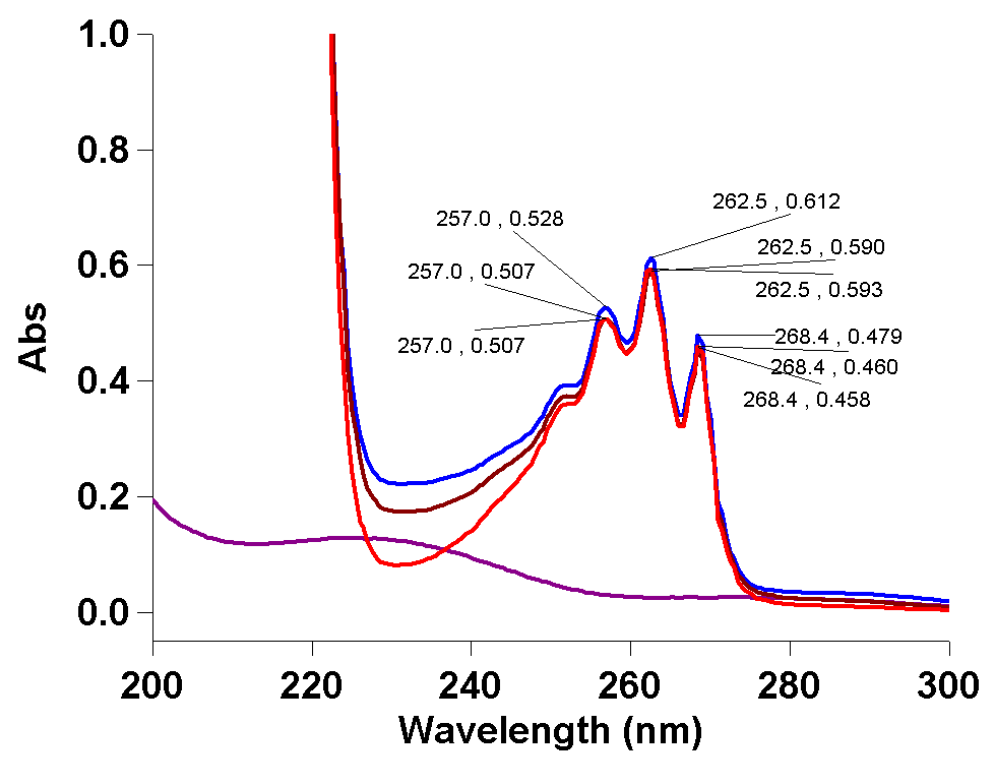

Рис. 3. Електронні спектри світлопоглинання випробовуваного розчину Дз (коричневий спектр), розчину порівняння (червоний спектр), розведеного МР ДЗ (синій спектр) та розчину плацебо (фріолетовий спектр) при дослідженні специфічності.

ISSN 2312-0967. Pharmaceutical review. 2021. № 1 
Аналіз лікарських засобів

\section{Analysis of drugs}

\section{Таблиця 2}

Результати дослідження стійкості розчину плацебо та розведеного МРДЗ при визначанні вмісту БАХ

\begin{tabular}{|c|c|c|c|c|c|}
\hline $\begin{array}{c}\text { Чинник } \\
\text { впливу }\end{array}$ & $\begin{array}{c}\text { Межі змін } \\
\text { досліджуваних } \\
\text { параметрів }\end{array}$ & Оптична густина & $\delta, \%$ & Критерій & Висновок \\
\hline \multirow{3}{*}{ Час, хв } & 0 & 0,4129 & 0 & \\
\cline { 2 - 4 } & 10 & 0,4135 & 0,15 & \multirow{2}{*}{ Відповідає } \\
\cline { 2 - 5 } & 30 & 0,4141 & 0,29 & \\
\cline { 2 - 5 } & 45 & 0,4134 & 0,12 & \\
\hline
\end{tabular}

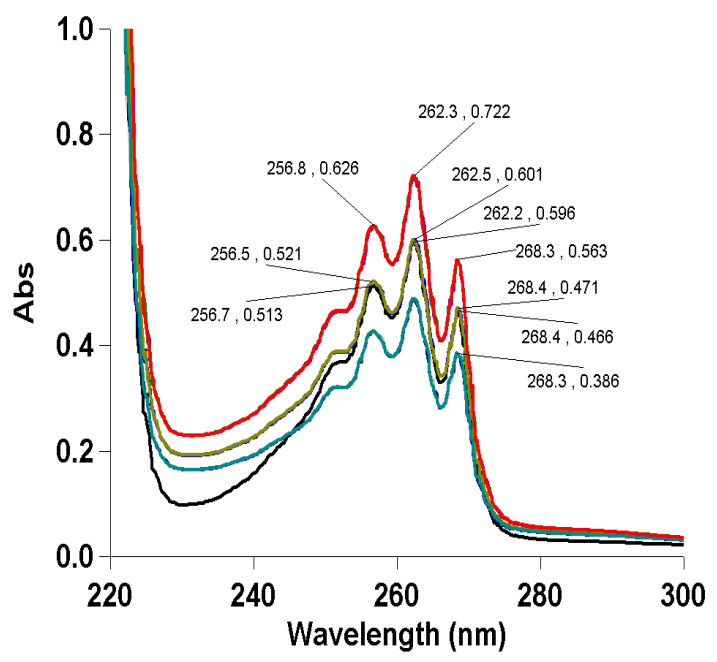

Рис. 4. Електронні спектри світлопоглинання розчину порівняння (чорний спектр) і розведених МР ДЗ (блакитний 80 \%, зелений - 100 \%, червоний - 120 \% від вмісту БАХ у деззасобі) при дослідженні лінійності, правильності та прецизійності.

Таблиця 3

Результати дослідження лінійної залежності абсорбції від концентрації БАХ

\begin{tabular}{|c|c|c|c|c|}
\hline $\begin{array}{c}\text { Позначення } \\
\text { розчину }\end{array}$ & $\begin{array}{c}\text { Теоретичний } \\
\text { вміст, \% }\end{array}$ & $\mathbf{V}_{i}$, мл & С, мкг/мл & $\mathbf{A}_{i}$ \\
\hline \multicolumn{2}{|c|}{ Розведений МРДЗ } & 5,00 & 496,2 & 0,4144 \\
\hline 1 & 80 & 4,00 & 404,2 & 0,3412 \\
\hline 2 & 80 & 4,00 & 404,2 & 0,3383 \\
\hline 3 & 80 & 4,00 & 404,2 & 0,340 \\
\hline 4 & 100 & 5,00 & 505,3 & 0,4194 \\
\hline 5 & 100 & 5,00 & 505,3 & 0,4137 \\
\hline 6 & 100 & 5,00 & 505,3 & 0,4125 \\
\hline 7 & 120 & 6,00 & 606,4 & 0,5031 \\
\hline 8 & 120 & 6,00 & 606,4 & 0,5049 \\
\hline 9 & 120 & 6,00 & 606,4 & 0,5008 \\
\hline
\end{tabular}

ISSN 2312-0967. Фармацевтичний часопис. 2021. № 1 
У таблиці 5 наведені критерії лінійності і обчислені параметри лінійної залежності для розробленої методики кількісного визначення БАХ у деззасобі «Віросан Ф».

\section{Прецизійність та правильність}

Результати аналізу розведених МР Дз та їхньої статистичної обробки наведені у таблиці 6.

\section{Внутрішньолабораторна прецизійність}

Аналіз проводив один аналітик, який використовував різний посуд і при цьому виконував по 5 паралельних вимірювань для однієї серії засобу в різні дні в одній лабораторії згідно з методикою кількісного визначення БАХ у деззасобі «Віросан Ф».

У таблиці 7 наведені метрологічні характеристики $[32,33]$ кількісного вмісту БАХ для дослідів 1 та 2.

Таблиця 4

Нормалізовані значення лінійної залежності аналітичного сигналу від концентрації БАХ у розведених МР ДЗ

\begin{tabular}{|c|c|c|c|c|}
\hline $\begin{array}{c}\text { Позначення } \\
\text { розчину }\end{array}$ & Теоретичний вміст, \% & $X_{i}=\frac{C_{i}}{C_{S t}} \cdot 100 \%$ & $Y_{i}=\frac{A_{i}}{A_{S t}} \cdot 100 \%$ & $Z_{i}=\frac{Y_{i}}{X_{i}} \cdot 100 \%$ \\
\hline 1 & 80 & 81,46 & 82,34 & 101,08 \\
\hline 2 & 80 & 81,46 & 81,64 & 100,22 \\
\hline 3 & 80 & 81,46 & 82,05 & 100,72 \\
\hline 4 & 100 & 101,83 & 101,21 & 99,38 \\
\hline 5 & 100 & 101,83 & 99,83 & 98,03 \\
\hline 6 & 100 & 101,83 & 99,54 & 97,75 \\
\hline 7 & 120 & 122,21 & 121,40 & 99,34 \\
\hline 8 & 120 & 122,21 & 121,84 & 99,70 \\
\hline 9 & 120 & 122,21 & 120,85 & 98,89 \\
\hline
\end{tabular}

\section{Таблиця 5}

Критерії лінійності та обчислені параметри лінійної залежності при кількісному визначенні БАХ

\begin{tabular}{|c|c|c|c|}
\hline $\begin{array}{c}\text { Позначення } \\
\text { параметра }\end{array}$ & Значення & Критерії & Висновок \\
\hline$b$ & 0,966 & - & Відповідає \\
\hline$S_{b}$ & 0,020 & $1) \leq 4,810$ & $2) \leq 5,118$ \\
\hline$a$ & 2,831 & - & (за першим критерієм) \\
\hline$S_{a}$ & 2,034 & $\leq 1,353$ & Відповідає \\
\hline$S_{0}$ & 1,166 & - & Відповідає \\
\hline$S_{y}$ & 17,65 & $\leq 0,9971$ & . \\
\hline
\end{tabular}

\section{Таблиця 6}

Результати аналізу розведених МРДз та їхньої статистичної обробки

\begin{tabular}{|c|c|c|c|}
\hline Параметри & Значення & Критерії & Висновок \\
\hline $\bar{Z}$ & 99,46 & - & Відповідає \\
\hline$S_{z}$ & 0,352 & $\leq 3,2$ & Відповідає \\
\hline$\Delta$ & 0,941 & 1) $\delta \leq 0,314 \%$ & 2) $\delta \leq 1,024 \%$ \\
\hline$\delta$ & $|-0,54|$ & (за другим критерієм) \\
\hline
\end{tabular}

ISSN 2312-0967. Pharmaceutical review. 2021. № 1 
Аналіз лікарських засобів

\section{Analysis of drugs}

\section{Таблиця 7}

Результати перевірки внутрішньолабораторної прецизійності методики кількісного визначення БАХ у препараті «Віросан Ф»

\begin{tabular}{|c|c|c|c|c|}
\hline \multirow{3}{*}{ Номер аналізу } & \multicolumn{4}{|c|}{$\mathrm{m}_{\mathrm{i}}, \mathrm{мг/мл}$} \\
\hline & \multicolumn{2}{|c|}{1 день (дослід 1) } & \multicolumn{2}{|c|}{2 день (дослід 2) } \\
\hline & $\Delta \mathrm{A}_{i}$ & $m_{i}^{1}$ & $\Delta \mathrm{A}_{i}$ & $m_{i}^{2}$ \\
\hline 1 & 0,4378 & 51,73 & 0,4254 & 51,00 \\
\hline 2 & 0,4387 & 51,83 & 0,4217 & 50,56 \\
\hline 3 & 0,4361 & 51,53 & 0,4361 & 52,28 \\
\hline 4 & 0,435 & 51,40 & 0,4271 & 51,21 \\
\hline 5 & 0,4319 & 51,03 & 0,4213 & 50,51 \\
\hline Середнє значення $(\bar{m})$ & & 51,50 & & 51,11 \\
\hline Об'єднане середнє ( $\left.\bar{m}_{\text {intra }}\right)$ & \multicolumn{4}{|c|}{51,31} \\
\hline $\mathrm{S}_{m}$ & \multicolumn{2}{|c|}{0,314} & \multicolumn{2}{|c|}{0,841} \\
\hline $\mathrm{S}_{\text {intra }}$ & \multicolumn{4}{|c|}{0,599} \\
\hline$\Delta_{\text {intra }}$ & \multicolumn{4}{|c|}{0,45} \\
\hline
\end{tabular}

Висновки. Запропоновано нову аналітичну методикукількісноговизначенняалкілбензилдиметиламоній хлориду в комбінованому деззасобі «Віросан Ф» методом прямої абсорбційної спектрофотометрії в ультрасріолетовій області однокомпонентним однохвильовим аналізом з використанням методу стандарту. Проведено основний етап валідації методики кількісного визначення БАХ у цьому деззасобі. Визначеними валідаційними характеристиками підтверджено, що розроблена методика придатна для контролю якості комбінованого деззасобу «Віросан Ф» за показником «Кількісне визначення».

Конфлікт інтересів: відсутній.

Conflicts of interest: authors have no conflict of interest to declare.

\section{VALIDATION OF THE METHOD OF QUANTITATIVE DETERMINATION OF ALKILDIMETHYLBENZYLAMMONIUM CHLORIDE BY THE METHOD OF DIRECT ABSORPTION SPECTROPHOTOMETRY IN THE DISINFECTANT "VIROSAN F"}

\section{Ya. Smolinska, H. Yu. Tesliar, I. Ya. Kotsiumbas, M. V. Yurkevych, L. I. Kotiasch}

State Scientific Research Control Institute of Veterinary Medicinal Products and Feed Additives

boiko_maria@ukr.net

The aim of the work. Development and validation of a method for quantitative determination of alkylbenzyldimethylammonium chloride with satisfactory metrological characteristics in the combined disinfectant "Virosan F" by direct UV-spectrophotometry. Materials and Methods. Disinfectant "Virosan F (LLC "BioTestLaboratory", Kyiv, Ukraine), which contains alkylbenzyldimethylammonium chloride $\left(50 \mathrm{mg} \cdot \mathrm{mL}^{-1}\right)$, glutaraldehyde and formaldehyde as active substances, as well as excipients was syntanol and purified water. In the work was used a secondary pharmacopoeial standard sample of alkylbenzyldimethylammonium chloride and excipients of pharmacopoeial purity (Sigma-Aldrich). Spectrophotometric measurements were performed on a scanning spectrophotometer Cary 50 Scan WinUV-Visible Spectrophotometer (Varian), in quartz cells with $10 \mathrm{~mm}$ path length.

Results and Discussion. The method of direct spectrophotometric determination of alkylbenzyldimethylammonium chloride in combination with two aldehydes (glutaral dialdehyde and formaldehyde) in aqueous solutions of one of the fairly common disinfectants "Virosan F" was developed and validated. The calculated values of the total predicted uncertainty do not exceed the maximum allowable systematic error of the results of the analysis of disinfectant "Virosan F". The placebo solution spectrum completely lacks all the light absorption maxima characteristic of alkylbenzyldimethylammonium chloride. The ratio of the absorption of the placebo solution to the absorption of the compensation solution is insignificant

ISSN 2312-0967. Фармацевтичний часопис. 2021. № 1 
compared to the maximum allowable systematic error of the analysis results. The dependence of the change in the values of the absorption of the model and test solutions of the disinfectant "Virosan F" on the storage time is insignificant compared to the maximum allowable systematic error of the analysis results. The determined parameters of linearity of the linear dependence of the analytical signal on the concentration of alkylbenzyldimethylammonium chloride in the model diluted solutions of disinfectant "Virosan F" meet the criteria of linearity, precision and accuracy. The value of $\Delta_{\text {intra, }}$, calculated when checking the intra-laboratory precision does not exceed the maximum allowable uncertainty of the analysis results. Compliance of all validation indicators with pharmacopoeial criteria is a reason to claim that the developed method is suitable for determining the content of alkylbenzyldimethylammonium chloride in the studied disinfectant.

Conclusions. A new analytical method for the quantitative determination of alkylbenzyldimethylammonium chloride in a combined disinfectant by direct absorption spectrophotometry in the ultraviolet region was proposed. The results of validation studies using acceptability criteria for tolerances of content deviation from the nominal value of $B= \pm 10 \%$, confirm the specificity, robustness, linearity, correctness, precision and intra-laboratory precision of the proposed method in the range of its application.

Key words: alkylbenzyldimethylammonium chloride; active pharmaceutical ingredient; quaternary ammonium compounds; disinfectants; spectrophotometry; validation.

\title{
ВАЛИДАЦИЯ МЕТОДИКИ КОЛИЧЕСТВЕННОГО ОПРЕДЕЛЕНИЯ АЛКИЛДИМЕТИЛБЕНЗИЛАММОНИЯ ХЛОРИДА МЕТОДОМ ПРЯМОЙ АБСОРБЦИОННОЙ СПЕКТРОФОТОМЕТРИИ В ДЕЗИНФИЦИРУЮЩЕМ СРЕДСТВЕ «ВИРОСАН Ф»
}

\section{М. Я. Смолинска, Г. Ю. Тесляр, И. Я. Коцюмбас, М. В. Юркевич, Л. И. Котяш}

\author{
Государственный научно-исследовательский контрольный институт ветеринарных препаратов \\ и кормовых добавок \\ boiko_maria@ukr.net
}

Цель работы. Разработка и проведение валидации методики количественного определения алкилдиметилбензиламмония хлорида с удовлетворительными метрологическими характеристиками в комбинированном дезинсекцирующем средств «Виросан Ф» методом прямой УФ-спектрофотометрии.

Материалы и методы. Средство дезиноицирующее «Виросан Ф» (ООО «БиоТестЛаборатория» Киев), содержащее в своем составе БАХ (50 мг $\cdot$ мл $\left.^{-1}\right)$, глутаровый альдегид и формальдегид как действующие вещества, а также вспомогательные вещества - синтанол и воду очищенную. В работе использовали вторичный фармакопейный стандартный образец алкилдиметилбензиламмония хлорида и вспомогательные вещества фрармакопейной чистоты (Sigma-Aldrich). Спектрофоотометрические измерения проводили на сканирующем спектрофотометре Cary 50 Scan WinUV-Visible Spectrophotometer (Varian) в кварцевых кюветах с толщиной поглощающего слоя $I=1 \mathrm{~cm}$.

Результаты и обсуждение. Разработано и проведено валидацию методики прямого спектрофротометрического определения алкилбензилдиметиламмоний хлорида в комбинации с двумя альдегидами (глутаровым диальдегидом и формальдегидом) в водных растворах одного из довольно распространенных дезиноиицирующих средств «Виросан Ф». Вычисленные значения полной прогнозируемой неуверенности не превышают максимально допустимой систематической погрешности результатов анализа дезсредства «Виросан Ф». На спектре раствора плацебо полностью отсутствуют все максимумы светопоглощения, характерные для алкилбензилдиметиламмоний хлорида. Отношение абсорбции раствора плацебо к абсорбции компенсационного раствора незначительно по сравнению с максимально допустимой систематической погрешностью результатов анализа. Зависимость изменения значений абсорбции модельных и испытуемых растворов дезсредства «Виросан Ф» от времени хранения является незначимой по сравнению с максимально допустимой систематической погрешностью результатов анализа. Определены параметры линейности линейной зависимости аналитического сигнала от концентрации алкилбензилдиметиламмоний хлорида в модельных разбавленных растворах дезсредства «Виросан Ф» соответствуют критериям линейности, прецизионности и правильности. Значение $\Delta_{\text {intra, }}$ исчисленная при проверке внутрилабораторной прецизионности, не превышает максимально допустимую неопределенность результатов анализа. Соответствие всех валидационных показателей фрармакопейным критериям является основанием утверждать, что разработанная методика пригодна для установления содержания алкилбензилдиметиламмоний хлорида в исследуемом дезсредстве.

Выводы. Предложена новая аналитическая методика количественного определения алкилбензилдиметиламмоний хлорида в комбинированном дезиноицирующем средстве методом прямой абсорбционной спектрофотометрии в ультрафиолетовой области, которая заключается в измерении абсорбции водных растворов БАХ при длине волны 268 нм. Расчет содержания предложено осуществлять методом стандарта. Результаты проведенных валидационных исследований с использованием критериев приемлемости для допусков отклонения содержания от номинального

ISSN 2312-0967. Pharmaceutical review. 2021. № 1 
Аналіз лікарських засобів

\section{Analysis of drugs}

значения В = $\pm 10 \%$ подтверждают специфичность, робасность, линейность, правильность, прецизионность и внутрилабораторную прецизионность предложенной методики в диапазоне ее применения от $4 \cdot 10^{-4} \Gamma \cdot$ мл $^{-1}$ до $6 \cdot 10^{-4} г \cdot$ мл $^{-1}$.

Ключевые слова: алкилдиметилбензиламмония хлорид; четвертичные аммонийные соединения; средства дезиноицирующие; спектрофротометрия; валидация.

\section{Список бібліографічних посилань}

1. Domagk G. A new class of disinfectant. Dtsch. Med. Wochenschr. 1935. Vol. 61, P. 829-832.

2. Абрамзон А. А., Зайченко А. П., Файнгольд С. И. Поверхностно-активные вещества. Синтез, анализ, свойства, применение; учебн. пособие для вузов. Л. : Химия, 1998. 200 с.

3. Gallo C., Rizzo P., Guerra G. Intercalation compounds of a smectite clay with an ammonium salt biocide and their possible use for conservation of cultural heritage. Heliyon. 2019. Vol. 5, No. 12.

4. The Japanese Pharmacopoeia 17-th Ed. (JP XVII), English Version, Tokyo: Pharmaceutical and Medical Devices Agensy, 2016.

5. Weston C. W., Papcun J. R., Dery M. Ammonium Compounds. Kirk-Othmer Encyclopedia of Chemical Technology, 2003.

6. Компендиум 2015 - лекарственные препараты / под ред. В. Н. Коваленко - К., 2015.

7. Bactericicidal, protistocidal and nematocidal propertiesjf mixtures of alkyldimethylbehzyl ammonium chloride, didecyldimethyl ammonium chloride, glutaradehyde and formaldehyde. V. V. Zazharskyi, P. Davydenko, O. Kulishenko et al. Regul. Mech. Biosyst. 2018. Vol. 9, No. 4, P. 540-545.

8. Листівка-вкладка ВІРОСАН Ф розчин для дезінфекції. URL: https://www.biotestlab.ua/ua/products/virosan-f/.

9. Spectrophotometric determination of benzalkonium chloride in dosage forms through charge-transfer complexation. F. Belal, M. I. Walash, F. A. Aly et al. Anal. Lett. 1997. Vol. 30, No 11, P. 1321-1335.

10. Two Spectrophotometric methods for the Assay of Benzalkonium Chloride in Bandage Samples. Weixing M., Xiaodong M., Ou S. et al. J Surfactants Deterg. 2014. Vol. 17, No 1, P. 177-181.

11. Method development and validation of benzalkonium chloride in marketed formulation by UV-visible spectrophotometry using silver nitrate and eosin solution. D. B. Meshram, P. Patel, P. Varshney et al. World J Pharm Pharmaceut Sci. 2014. Vol.3, No. 2, P. 14811487.

12. Parkin J.E. The assay of benzalkonium chloride in pilocarpine, hypromellose and polyvinyl alcohol ophthalmic drops by secondorder derivative ultraviolet spectrophotometry. J Pharmaceut Biomed. 1993. Vol. 11, No 7, P. 609-611.

13. Hassouna M.E.M., Abdelrahman M.M., Mohamed M.A. Determination of azelastine hydrochloride and benzalkonium chloride in their ophthalmic solution by different spectrophotometric methods. World J Appl Chem. 2017. Vol. 2, No. 2, P. 48-56.

14. Kovács-Hadady K., Fábián I. The determination of ben- zalkonium chloride in eye-drops by difference spectrophotometry. J Pharmaceut Biomed. 1998. Vol. 16, No. 5, P. 733-40.

15. Ghasemi Z., Parham H. Determination of trace amounts of benzalkonium chloride by liquid-liquid extraction-spectrophotometry method. Asian J. Chem. 2011. Vol. 23, No. 10, P. 4464-4466.

16. Rapid determination of benzalkonium chloride in pharmaceutical preparations with flow injection liquid-liquid extraction. J. J. Halvax, G. Wiese, J. A. Arp et al. J Pharmaceut Biomed. 1990. Vol. 8, No. 3, P. 243-52.

17. Development and validation of a rapid ultra-high performance liquid chromatography method for the assay of benzalkonium chloride using a quality-by-design approach. R. Mallik, S. Raman, X. Liang et al. J. Chromatogr. A. 2015. Vol. 1413, P. 22-32.

18. Quality by design based optimization of a high performance liquid chromatography method for assay determination of low concentration preservatives in complex nasal formulations. J. Zakrajšek, V. Stojic, S. Bohanec et al. Acta Chim. Slov. 2015. Vol. 62, No. 1, P. 72-82.

19. Al-Aani H., Al-Nukkary Y. Determination of benzalkonium chloride in ophthalmic solutions by stability-indicating HPLC method: application to a stability study. J. Appl. Pharmaceut. Sci. 2016. Vol. 6, No. 05, P. 80-89.

20. Santos M., Li M., Rustum A.M. A single RP-LC method for the determination of benzalkonium chloride and its potential impurities in benzalkonium chloride. Raw Mat. Chromatogr. 2010. Vol. 71, No. 5-6, P. 499-503.

21. Chyła A. Zelazowska E. Using of thin-layer chromatography for identification and quantitative determination of benzalkonium chloride in eye drops. Acta Pol. Pharm. 1999. Vol. 56, No. 6, P. 419-423.

22. Cybulski Z.R. Determination of benzalkonium chloride by gas chromatography. J. Pharm. Sci. 1984. Vol. 73, No. 12, P. 1700-1702.

23. Kang H.I., Shin H.S. Rapid and sensitive determination of benzalkonium chloride biocide residues in soil using liquid chromatography-tandem mass spectrometry after ultrasonically assisted extraction. B Korean Chem.Soc. 2016. Vol. 37, No. 8, P. 1219-1227.

24. Hou Y. H., Wu C. Y., Ding W. H. Development and validation of a capillary zone electrophoresis method for the determination of benzalkonium chlorides in ophthalmic solutions. J. Chromatogr. A. 2002. Vol. 976, No. 1-2, P. 207-213.

25. Determination of benzalkonium chloride preservative in pharmaceutical formulation of eye and ear drops using new potentiometric sensors. M. G. Hazem, M. A. Shawish, A. M. Khedr et al. Mater. Sci. Eng. C. 2012. Vol. 32, No. 8, P. 2299-2305.

26. European Pharmacopoeia (Eur. Ph.). 8-th Ed. Stras-

ISSN 2312-0967. Фармацевтичний часопис. 2021. № 1 
bourg: Council of Europe, 2016.

27. The British Pharmacopoeia (BP), Intern. Ed. London: H.M. Stationary Office, 2013.

28. United States Pharmacopoeia, USP 40-NF35 Convention Inc., Rockville: The United States Pharmacopeial Convention, 2016.

29. Державна Фармакопея України: в 3 т. / Державне підприємство «Український науковий фрармакопейний центр якості лікарських засобів». 2-е вид. Харків : Державне підприємство «Український науковий фрармакопейний центр якості лікарських засобів», 2015. Т. 1, С. 910-929.

30. Настанова Eurochem «Придатність аналітичних методів для конкретного застосування. Настанова

\section{References}

1. Domagk G. A new class of disinfectant. Dtsch Med Wochenschr. 1935;61: 829-32.

2. Abramzon AA, Zaychenko AP, Fayngold SI. Surfactants. Synthesis, analysis, properties, application; textbook for universities. [Поверхностно-активные вещества. Синтез, анализ, свойства, применение; учебн. пособие для вузов] Leningrad: Khimiya; 1998. Russian.

3. Gallo C, Rizzo P, Guerra G. Intercalation compounds of a smectite clay with an ammonium salt biocide and their possible use for conservation of cultural heritage. Heliyon. 2019;5(12). DOI: 10.1016/j.heliyon.2019. e02991.

4. The Japanese Pharmacopoeia 17-th Ed. (JP XVII), English Version, Tokyo: Pharmaceutical and Medical Devices Agensy, 2016.

5. Weston CW, Papcun JR, Dery M. Ammonium Compounds. Kirk-Othmer Encyclopedia of Chemical Technology; 2003.

6. Kovalenko VN. Compendium 2015 - drugs. [Компендиум 2015 - лекарственные препараты] 2015. Russian.

7. Zazharskyi VV, Davydenko P, Kulishenko O, Chumak V, Kryvaya A, Biben IA et al. Bactericicidal, protistocidal and nematocidal propertiesjf mixtures of alkyldimethylbehzyl ammonium chloride, didecyldimethyl ammonium chloride, glutaradehyde and formaldehyde. Regul Mech Biosyst. 2018;9(4): 540-45. DOI: 10.15421/021881.

8. Card-tab VIROSAN F solution for disinfection [Ly`stivka-vkladka VIROSAN F rozchy`n dlya dezinfekciyi]. https://www.biotestlab.ua/ua/products/virosan-f/.

9. Belal F., Walash MI, Aly FA, Mesbah AO Spectrophotometric determination of benzalkonium chloride in dosage forms through charge-transfer complexation. Anal Lett. 1997;30(7): 1321-35. DOI: 10.1080/00032719708007219.

10. Weixing M, Xiaodong M, Ou S, Yinghong L Two spectrophotometric methods for the assay of benzalkonium chloride in bandage samples. J Surfactants Deterg. 2014; 17 (1): 177-81. DOI: 10.1007/s11743-013-1446-4.

11. Meshram DB, Patel P, Varshney P, Dhara P Method development and validation of benzalkonium chloride in для лабораторій з валідації методів та суміжних питань» / за редакцією Б. Магнуссона та У. Ернемарка ; переклад другого видання 2014 р. Київ : Тов «Юрка Любченка», 2016 . 92 с.

31. Настанова Eurochem «Термінологія аналітичного вимірювання. Вступ до VIM 3» / за редакцією V. Bavick та E. Prichard ; переклад першого видання 2011 р. Київ : ДП «Укрметртестстандарт», EurochemUkraine, 2015.77 c.

32. Дворкин В. И. Метрология и обеспечение качества количественного химического анализа. Москва : Химия, 2001. 263 с.

33. Гармаш А. В., Сорокина Н. М. Метрологические основы аналитической химии. Москва : Изд-во МГУ, 2005.42 с.

marketed formulation by UV-visible spectrophotometry using silver nitrate and eosin solution. World J Pharm Pharmaceut Sci. 2014;3(2): 1481-87.

12. Parkin JE The assay of benzalkonium chloride in pilocarpine, hypromellose and polyvinyl alcohol ophthalmic drops by secondorder derivative ultraviolet spectrophotometry. J Pharmaceut Biomed. 1993;11(7): 60911. DOI: 10.1016/0731-7085(93)80012-P

13. Hassouna MEM, Abdelrahman MM, Mohamed MA Determination of azelastine hydrochloride and benzalkonium chloride in their ophthalmic solution by different spectrophotometric methods. World J Appl Chem. 2017;2(2): 48-56. DOI: 10.11648/j.wjac.20170202.12

14. Kovács-Hadady K, Fábián I The determination of benzalkonium chloride in eye-drops by difference spectrophotometry. J Pharmaceut Biomed. 1998;16(5): 73340. DOI: 0.1016/s0731-7085(97)00085-X

15. Ghasemi Z, Parham H. Determination of trace amounts of benzalkonium chloride by liquid-liquid extraction-spectrophotometry method. Asian J Chem. 2011;23(10): 4464-66.

16. Halvax JJ, Wiese G, Arp JA, Vermeer JM, Van-Bennekom WP, Bult A. Rapid determination of benzalkonium chloride in pharmaceutical preparations with flow injection liquid-liquid extraction. J Pharmaceut Biomed. 1990;8(3): 243-52. DOI: 10.1016/0731-7085(90)80033-L

17. Mallik R, Raman S, Liang X, Grobin AW, Choudhury D. Development and validation of a rapid ultra-high performance liquid chromatography method for the assay of benzalkonium chloride using a quality-by-design approach. J Chromatogr A. 2015;1413: 22-32. DOI: 10.1016/j.chroma.2015.08.010

18. Zakrajšek J, Stojic V, Bohanec $S$, Urleb U Quality by design based optimization of a high performance liquid chromatography method for assay determination of low concentration preservatives in complex nasal formulations. Acta Chim Slov. 2015;62(1): 72-82. DOI: 10.17344/acsi.2014.718

19. Al-Aani H, Al-Nukkary $\mathrm{Y}$ Determination of benzalkonium chloride in ophthalmic solutions by stability-indicating HPLC method: application to a stability study. J Appl Pharmaceut Sci. 2016;6(05): 80-9. DOI: 10.7324/ JAPS.2016.60513

ISSN 2312-0967. Pharmaceutical review. 2021. № 1 
20. Santos M, Li M, Rustum AM A single RP-LC method for the determination of benzalkonium chloride and its potential impurities in benzalkonium chloride raw material. Chromatogr. 2010;71(5-6): 499-503. DOI: 10.1365/ s10337-009-1458-4

21. Chyła A, Zelazowska E Using of thin-layer chromatography for identification and quantitative determination of benzalkonium chloride in eye drops. Acta Pol Pharm. 1999;56(6): 419-23.

22. Cybulski ZR Determination of benzalkonium chloride by gas chromatography. J Pharm Sci. 1984;73(12): 1700-02. DOI: 10.1002/jps.2600731209

23. Kang HI, Shin HS Rapid and sensitive determination of benzalkonium chloride biocide residues in soil using liquid chromatography-tandem mass spectrometry after ultrasonically assisted extraction. B Korean Chem Soc. 2016;37(8): 1219-27. DOI: 10.1002/bkcs.10842

24. Hou YH, Wu CY, Ding WH Development and validation of a capillary zone electrophoresis method for the determination of benzalkonium chlorides in ophthalmic solutions. J Chromatogr A. 2002;976(1-2): 207-13. DOI: 10.1016/s0021-9673(02)00943-3.

25. Hazem MG, Shawish MA, Khedr AM, Abed-Almonem KI Determination of benzalkonium chloride preservative in pharmaceutical formulation of eye and ear drops using new potentiometric sensors. Mater SciEng C. 2012;32(8): 2299-305. DOI: 10.1016/j.msec.2012.06.018
26. European Pharmacopoeia (Eur. Ph.). 8-th Ed. Strasbourg: Council of Europe, 2016.

27. The British Pharmacopoeia (BP), Intern. Ed. London: H.M. Stationary Office, 2013.

28. United States Pharmacopoeia, USP 40-NF35 Convention Inc., Rockville: The United States Pharmacopeial Convention, 2016.

29. State Pharmacopoeia of Ukraine. [Державна Фармакопея України: в 3 т.]. 2nd ed., Vol. 1. Kharkiv: Ukrainian Scientific Pharmacopoeial Center for Quality of Medicines; 2015. Ukrainian.

30. Eurachem Guide: The Fitness for Purpose of Analytical Methods - A Laboratory Guide to Method Validation and Related Topics: B. Magnusson and U. Örnemark (eds.): translation of the second edition, 2014 Kyiv: LLC "Yurka Liubchenka"; 2016.

31. Barwick V J, Prichard E. (Eds.). Eurachem Guide: Terminology in Analytical Measurement - Introduction to VIM 3 (2011). ISBN 978-0-948926-29-7.

32. Dvorkin VI Metrology and quality assurance of quantitative chemical analysis. [Метрология и обеспечение качества количественного химического анализа] Moskow: Khimiya; 2001. Russian.

33. Garmash AV, Sorokina NM. Metrological foundations of analytical chemistry. [Метрологические основы аналитической химии] Moscow: MSU publishing house; 2005. Russian.

\section{Відомості про авторів}

Смолінська М. Я. - канд. хім. наук, завідувач сектора фрармакопейних методів контролю лабораторії високоесективної рідинної хроматограсрії, Державний науково-дослідний контрольний інститут ветпрепаратів та кормових добавок, Львів, Україна. e-mail: boiko_maria@ukr.net, ORCID 0000-0003-2547-2883.

Тесляр Г. Ю. - старший науковий співробітник сектора фрармакопейних методів контролю лабораторії високоефрективної рідинної хроматографії, Державний науково-дослідний контрольний інститут ветпрепаратів та кормових добавок, Львів, Україна. e-mail: tesgav@gmail.com, ORCID 0000-0002-2377-6405.

Коцюмбас І. Я. - д. вет. наук, директор Державного науково-дослідного контрольного інституту ветпрепаратів та кормових добавок, Львів, Україна. e-mail: dir@scivp.Iviv.ua, ORCID 0000-0002-9287-3997.

Юркевич М. В. - науковий співробітник сектора фрармакопейних методів контролю лабораторії високоефективної рідинної хроматограсрії, Державний науково-дослідний контрольний інститут ветпрепаратів та кормових добавок, Львів, Україна. e-mail: marianna05@ukr.net, ORCID 0000-0002-6601-8102

Котяш л. І. - науковий співробітник сектора фрармакопейних методів контролю лабораторії високоефективної рідинної хроматографії, Державний науково-дослідний контрольний інститут ветпрепаратів та кормових добавок, Львів, Україна. e-mail: Ikotyash@ukr.net, ORCID 0000-0001-6324-9020.

\section{Information about the authors}

Smolinska M. Ya. - PhD (Chemistry), Head of the Sector of the Pharmacopoeia Control Methods Laboratory of Highperformance Liquid Chromatography, State Scientific Research Control Institute of Veterinary Preparations and Fodder Additives, Lviv, Ukraine. e-mail: boiko_maria@ukr.net, ORCID 0000-0003-2547-2883.

Tesliar H. Yu. - senior researcher, Sector of the Pharmacopoeia Control Methods Laboratory of High-performance Liquid Chromatography, State Scientific Research Control Institute of Veterinary Preparations and Fodder Additives, Lviv, Ukraine. e-mail: tesgav@gmail.com, ORCID 0000-0002-2377-6405.

Kotsiumbas I. Ya. - DSc (Veterinary), Professor, Head of the State Scientific Research Control Institute of Veterinary Preparations and Fodder Additives, Lviv, Ukraine. e-mail: dir@scivp.Iviv.ua, ORCID 0000-0002-9287-3997.

Yurkevych M. V. - researcher, Sector of the Pharmacopoeia Control Methods Laboratory of High-performance Liquid Chromatography, State Scientific Research Control Institute of Veterinary Preparations and Fodder Additives, Lviv, Ukraine. e-mail: marianna05@ukr.net, ORCID 0000-0002-6601-8102.

Kotiash L. I. - researcher, Sector of the Pharmacopoeia Control Methods Laboratory of High-performance Liquid Chromatography, State Scientific Research Control Institute of Veterinary Preparations and Fodder Additives, Lviv, Ukraine. e-mail: Ikotyash@ukr.net, ORCID 0000-0001-6324-9020.

ISSN 2312-0967. Фармацевтичний часопис. 2021. № 1 